Nepal. A Draft Paper Prepared during the Writing Workshop, November 5-19, 2001. CIFOR, Bogor, Indonesia.

Thesis, Joachin and Grody, H.M. 1991. Participatory Rapid Appraisal for Community Development. International Institute for Environment and Development and Save the Children Federation.

Uprety, Laya Prasad.2001. Participatory Research and Gender Analysis Impact Assessment. New ERA, Kathmandu.

Uprety, Laya Prasad, Narayan Sitoula and Kalpana Sharma, 2001. Background Study for Adaptive Co-management: A Final Report Submitted to CIFOR, Bogor, Indonesia. New ERA, Kathmandu.

Uprety, Laya Prasad, Narayan Sitoula and Kalpana Sharma. Adaptive and Collaborative Management in Community Forestry in Nepal: A Final Report of Main Case Studies of Manakamana and Andheribhajana Community Users' Groups of Sankhuwasabha District Submitted to CIFOR, Bogor, Indonesia. New ERA, Kathmandu.

\section{CHANGING PATTERN OF FOREST CONSUMPTION: A CASE STUDY FROM AN EASTERN HILL VILLAGE IN NEPAL}

Binod Pokharel ${ }^{*}$

\section{Preliminary}

This is a longitudinal study on the changing pattern of forest consumption in Belahara Village Development Committee of Dhankuta district for the period 2001 to 1991. The author carried out a follow up study in 2001 and compared it with the results of the study conducted by the author in 1991 for his thesis research in M.A. degree in Anthropology to know the changing behavior of forest consumption in the study area. The follow up study attempts to find out the changing factors associated with forest consumption behaviour of the people. Similarly, this article also compares and contrasts the past and present forest consumption pattern of the study area.

In 1991 there were 750 households (HHs) at the VDC. Out of a total of $750 \mathrm{HHs} 80 \mathrm{HHs}$ were selected for the study. During the period of follow up study, the family members of the same 80 sampled houses were separated from original households for data collection (few of them were found to leave their village and get settled down along the road). The major tools and techniques used in the study were formal/informal

Mr. Binod Pokharel is the Lecturer in Anthropology at the Central Department of Sociology/Anthropology, Tribhuvan University, Kirtipur, Kathmandu. 
interview, interview schedule and observation. The data gathered from original and follow up studies were compared with the help of tables. The data were analyzed using descriptive statistical tool such as percentage.

\section{Review}

\subsection{Utilization of Forest}

Forest resources are essential to the livelihood (Fricke, 1993) of the people who live in subsistence agriculture economy. Forest is used for several purposes like cooking, heating, lighting, etc. As stated by Beresford (1968), there are manifold uses of forest in the world, viz. cultivation, fuel wood for cooking, and timber for consumption of homes. Forest bio-mass is the main source of energy in the world. Of all the wood cut in the forest of the world around half is burnt as domestic fuel (Ibid). Historically, Nepal's rural populations have been meeting the energy needs from the traditional sources like fuel-wood and other bio-mass resources (AEPC, 2000). Firewood shares the highest percentage of consumption of the country. MoF (2001) noted that of the total energy demand of the country, $77.7 \%$ is met from the firewood. Firewood is a basic source of energy for cooking in most part of the rural areas in Nepal. The second most commonly used fuel is dung. The use of firewood is highly prominent in the mountain and the hill areas (CBS, 2002). The role of liquefied petroleum gas (LPG), electricity and kerosene in cooking purposes in still negligible. CBS (2002) stated that cent percent households in the Far Western region are found to use firewood for cooking purpose. The utilization of dung is widely common in the eastern Tarai. The use of dung for energy gradually decreases as we move on to the west from the east (Ibid). Share of the rural areas in total energy consumption of the country is about $87 \%$. Rural sector accounts for $89 \%$ of the total rural energy consumption. However, if only commercial energy (including new and renewable energy) is considered, then the rural areas consume only $30 \%$ of total commercial energy consumption (WECS, 1995 quoted by AEPC, 2000).

Forestry plays an important role in sustaining the productivity of the land by using the organic manure of animal dung supported with bedding materials from the forest which provides grass, trees and fodder for animals (ADB/N, HMG/N, 1982 : 63). It is considered a very important contribution of forestry to hill farming in the use of plant bio-mass, when mixed with animal excreta yields organic compost manure which forms the principal source of soil nutrients for hilly agricultural land (ICIMOD, 1987:8). Fuel for cooking fires and warmth, lumber for roofing, floor planks and household timbers and the raw materials for the whole array of household and farm tools come from the forest area in Tamang village (Fricke, 1993). Lacking sufficient supply of fossil fuel as well as industrial fuel Nepal has heavily relied on fuelwood as main source of energy. It is estimated that the fuel-wood is the source of 83.7 percent of energy used (WECS,1987:1) and per capita consumption of energy is equivalent to 490 kilograms of coal in Nepal energy (Economic Survey, 1989). There is a considerable variation in the consumption of fuel wood in the different regions of the country. In the rural hills, consumption ranges from about 0.7 cum in the central region to nearly 1.2 cum in the east. Consumption in the rural Terai ranges from less than $0.6 \mathrm{cum}$, ranges from less than $0.6 \mathrm{cum}$, in the central region to over 1.4 cum in the mid-West and for west (WEC, 1988, cited by Wallace, 1988: 5). These figures show that hilly people consume more fuelwood than urban and Terai dwellers do. Fricke (1993) stated that fuel consumption varies by season in Tamang village. During the cold months of November through February, households burn nearly one load a day, while a load will last close to five days in the other months. Stevens (1993) noted that Sherpa's household firewood use varies seasonally and also with wealth, household size and labour resources, and the accessibility of forest. Forest consumption pattern is also affected by some important variables like class, caste/ethnicity and family size. In this regard Pokharel (1991) mentioned that some ethnic groups like Rai, Tamang and Newar consumed more firewood than Brahmin and Chhetry because of cultural reasons. People collect firewood from different sources. In this regards one report (CBS, 2002) states that 
More than two-thirds of the households collect firewood from the forest. The other form of collection of firewood is from the land owned by the households. In rural Nepal 68 percent of the households reported collecting firewood from the jungle and the community forests whereas 25 percent households reported such collection being done from their own land. Only 5 percent of the households purchase firewood from the market.

Fodder from the forest is the most important for livestock, especially at certain times of the year when grasses are unavailable at agricultural land. As mentioned by FAO $(1985 ; 12)$ in arid areas, trees often provide regular supplies of fodder in the form of edible seeds and pods and leaves. During the time of drought, they become important sources of animal feed. Timber is considered the major construction material of the huts, houses and buildings in Nepal. Malla et. al (1981) mentioned that the per capita timber consumption in Nepal is 8 cu.ft per year.

\subsection{History of Forest Management and Consumption}

Prior to 1957 most of the forests were under control of local community. The traditional forest management strategies followed the principle of considering the needs of local people. Pokharel et. al. (1996) stated that before 1957 nobody could cut trees to thatch or collect fodder from the forest without local indigenous organization's permission. Permission to cut down fuelwood was granted depending on household size, and gathering of thatching grass was allowed in proportion to roof area of a house. Hence, the forest utilization behaviour was largely controlled by the local organization in the past. Many literatures on forestry analysed the forest situation of Nepal before 1957 in terms of Management. Gilmour and Fisher (1991) noted that Nepal had different forest management strategies in different historical epoch. As stated during the unification period Thari and Jimbuwal were responsible to control the forest and the government looked after few forests. They made rules, regulations and operational plan. Dahal (1993) notes that before 1964, there existed primarily Kipat and Raikar system of land tenure in the Eastern Hill Region. Both land and forest resources were held under the Subba, Jimuwal, Pahari, and Thari. They were responsible for both the sustainable use of the resources and its allocation. It is said that people's forest consumption behaviour was regularized by the local and traditional organizations in the past.

The literatures of forestry show that the process of deforestation started just after the nationalization of forest. Many countries of Asia, Africa and Latin America experienced massive deforestation under the state led forestry strategy. Ten countries in the developing world that contained substantial areas under forest in the past were at present in a state of acute fuelwood "scarcity". This list includes Ethiopia, Nigeria, Senegal and Tanzania in Africa; Afganisthan, Bangladesh and Nepal in Asia, Haiti and Peru in Latin America (Noronha and Spears, 1985). Noronha and Spears (1985) viewed that in 1970 international agencies' concentration on the protection and management of government owned forest reserves was questioned. Forestry for the people heralded a new approach to forestry development in Jakarta in 1978. Nepal also practiced different type of forest management in the name of Panchayat forest, Panchayat protected forest, leasehold forest, etc after the world forestry congress in 1978. However, the effect of late 1970 s approach of community forestry hardly changed the forestry scenario of the country. In this regards Dahal (1994) says that the Panchayat forest, and the Panchyat protected forest could not function effectively as there was little participation at the local level and the forest rules were simply confined to the file of the Pradhan Pancha. He viewed that the sensitivity of the village people and their forest product requirements were hardly considered by the village leadership.

In late 1980 s, the concept of community forest emerged as new approach. The approach focused on people-centered forestry management. The approach of community forestry in Nepal emerged in response to an increasing awareness of the implication of decling forestry (Saussan et. al, 1995). However, several scholars (Chhetri and Panday, 1992, and Baral and Lamsal, 1991) viewed that community forestry was started in 
Nepal because of the existence of indigenous forest management system.

After the government intervention in forestry sector late 1980s and early 1990s, several changes have been experienced in the field of forest consumption. The mode of behaviour of people have changed because of outside factors such as government intervention, population growth, migration, integration into national and global economy and other processes. Because of new invention, people have developed many adjustments to obtain and use resources. In this regards, Stevens (1993) states the people of Himalayan like highland regions, have developed for subsisting the distinctive conditions of ecosystems.

\section{The Study Area}

The study area lies on the western part of the district capital of Dhankuta. The area under study is located on the ridge of Belahara and alluvial basins of Patle Khola, Ruduwa Khola and Tamor river. The eastern and southern part of the study village is touched by Dharan-Dhankuta highway. Hile-Chhintang fair weather road connects the northern and western part of the VDC. In the study the forest covers area $22 \%$ of the total land. The contribution of the forest to the people of the Belahara includes fuelwood, timber, fodder, some fruits and vegetables.

The total population of the village is 5720 comprising 2807 female and 2413 male with 1028 households (VDC, 2001). The Rais (20\%) are the dominant group of the village followed by Chhetries(15\%), Tamang(13\%), Magars(13\%), Kamis(12\%), Damais(11\%), Newars(10\%) and Brahamin $(6 \%)$.

\section{Forest History of the Study Area}

Like in other parts of the country, the forest of the study area was under the control of local indigenous group of people called Athpaharia Rai. The authority of the Athpahariyas later shifted into Jhari and Jimbuwal of the Chhetry and Brahmin groups. As noted there was dense forest in the village upto 1970.
It is said that the forest of the village was under the control of local people even after it was nationalized in 1957. As reported, Forest Nationalization Act became effective only after the late 1960s. In 1970s, Dhankuta was declared as development center of Eastern Development Region. During that time, a large number of regional level government offices were established. Population influx of the district headquarters increased because of offices. As told by informants, the fuelwood demand of the district headquarters was fulfilled by the adjoining areas like Belahara, Bhirgoan, Atmara, etc. Similarly, at the same time, government and individuals began to construct the houses for line agencies. As recorded most of the timber demand of the headquarters was supplied from the area under study. The other major upheavals and change of the forestry of the study area were Dharan- Dhankuta Highway. Thirteen kilometers of highway, out of $52 \mathrm{k} . \mathrm{m}$. passes through village territory from Tamor river to Patle Khola., this brought tremendous changes in many aspects of the social life of the village. The transportation changed the settlement pattern of the village from the scattered to concentrating trend along the highway as well as the pattern of using forest resources. During the construction period of road 13 $\mathrm{km}$ forested area was destroyed from Tamor river to Patle Khola. After the construction of road, the naturally protected forest on steeper slopes of Southern part which was far from the villages, also experienced massive destruction due to cutting down of piles of Khair (Acacia Catechu) trees and fuelwood for their sale in market as well as personal use. The construction of highway encouraged the people of other areas also to exploit this forest. During the first field visit in 1991, 200 bhari $(1$ Bhari $=30 \mathrm{~kg}$ ) of firewood was supplied to Dhankuta bazaar from the area under study. Hence, the opening of the highway had intensified the process of degradation in several ways. As noted the process of forest degradation continued in the beginning of 1991. The concept of community forest was introduced in the study area around 1993. Now there are 157 forest user groups. After 1993, 
many changes have taken place in forest consumption behaviour of the people. People developed several adaptive strategies to cope with changing pattern of forest management.

\section{Adaptive Process of People}

After the establishment of community forest (CFs) in the area people were confined to be the member of particular community forestry. Prior to $\mathrm{CF}$, one could get the firewood from any forest of the village. Because of heavy deforestation between the period of 1970-1990, people felt scarcity of firewood. Community forestry approach also established some rules with regard to forest products. Both deforestation and $\mathrm{CF}$ controlled the easy access of people on forest. To cope with changing situation, they developed several strategies to fulfill their energy demand. Adaptive strategy denotes those patterns formed by the many separate adaptive processes (Bennet, 1996). In 1991, there was complete absence of alternative source of energy throughout the village. Out of 80 hhs, 35 hhs were found installing bio-gas during the period of follow up study. In the past some ethnic group like Rai, Tamang, Newar and Kami used more firewood than other groups because a function of cultural needs. Except heating and cooking, they used firewood for wine making. Because of market intervention distillery products displaced their alcohol-brewing business. The factory made alhocol gave the death blow to the local alcohol-brewing business, . Scarcity of charcoal gave pressure to the blacksmith to abandon their crafting business. In 1991, eight households, out of ten were under patron -client relationship but after a decade, only 2 houses were noticed involving in their traditional occupation. The community forestry was strictly restricted to make charcoal from the forest of VDC under study. People's dependency on firewood was high in 1991. However, the dependency on forest had significantly decreased in 2001.
Table- 1 Changing Pattern of Firewood Consumption on the Basis of Caste and Ethnicity

\begin{tabular}{|c|c|c|c|c|c|c|c|}
\hline \multicolumn{5}{|c|}{ Main Source of Fuel, 1991} & \multicolumn{3}{|c|}{ Main Source of Fuel, 2001} \\
\hline$\frac{\dot{0}}{\frac{\pi}{0}}$ & 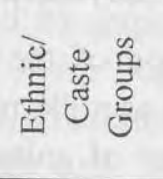 & 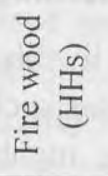 & 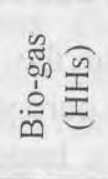 & 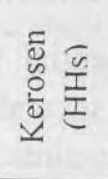 & $\begin{array}{l}\square \\
0 \\
\vdots \\
\vdots \\
\vdots \\
\vdots\end{array}$ & 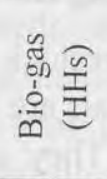 & 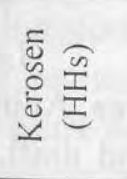 \\
\hline 1 & Rai & 10 & & & 6 & 4 & \\
\hline 2 & Chhetry & 10 & 11 & & 2 & 8 & \\
\hline 3 & Magar & 10 & & & 7 & 3 & \\
\hline 4 & Brahmin & 10 & & & 2 & 8 & \\
\hline 5 & Tamang & 10 & & & 6 & 4 & \\
\hline 6 & Newar & 10 & & & 2 & 5 & 3 \\
\hline 7 & Kami & 10 & & & 8 & 2 & \\
\hline 8 & Damai & 10 & & & 9 & 1 & \\
\hline Total & & 80 & & & 42 & 35 & 3 \\
\hline
\end{tabular}

Source : Field Survey, 1991-2001

The table 1 shows the change coming in firewood consumption pattern between the period of 1991-2001. There are three factors which force the people to use bio-gas. The first one is that the CFs fixed the amount of firewood requirement of each household. One can harvest firewood one time in a year, which is barely sufficient for them. The second one is subsidy on biogas encouraged the people to install it. The last one is people's awareness on forest preservation. At the national level, the percentage of households using alternation sources of energy (LPG, Kerosene, Bio-gas, etc.) in the rural areas is negligible. However, the percentage of using bio-gas in the area under study is high because of government intervention and transportation facilities. However, bio-gas is still used for limited purposes i.e. cooking. Use of bio-gas for lighting was not common through out the VDC. As observed bio-gas is used for cooking two times meal and one time snack in a day. During the course of big feast and festivals, all of the users of the bio-gas also use firewood for 
cooking. All of the sampled households use firewood for preparing Khole (gruel).

\section{b. Changing Herd Composition and Herding Movement}

Livestock are essential to the livelihood of the study area. Animals are kept for several purposes such as milk, manure and draft. They used to maintain large number of animals in 1991. As recorded in 1991, the average size of livestock holding per household was 9. Now this number had significantly declined to 5 . The community forestry had restricted the animal grazing in the forest freely. The respondents of the study area would collect the fodder only on seasonal basis . In 1991, leaf and grass from forest were the main sources of animal feed. After the formation of forest user groups, crop residue (straw) was the major source of fodder. To cope with the fodder scarcity, the respondents started to grow fodder trees at their agricultural land. In 1991, only 17 households independently provided year round fodder for the animal. Now, the number of independently fodder supplier household reached 25 in 2001. The size of livestock of two different period has been presented in tables 2 .

Table : 2 Comparison of Livestock Size of two Different Periods.

\begin{tabular}{llcc}
\hline S.N. & Type of Animal & $\begin{array}{c}\text { Total Number in } \\
1991\end{array}$ & $\begin{array}{c}\text { Total Number in } \\
2001\end{array}$ \\
\hline 1 & Cows & 182 & 82 \\
2 & Oxen & 134 & 50 \\
3 & Buffaloes & 68 & 70 \\
4 & Goats & 274 & 130 \\
\hline 5 & Pigs & 90 & 110 \\
\hline
\end{tabular}

Source : Field Survey, 1991-2001

The number of all animals except the pig had decreased. The causes of decrease were several such as installation of bio gas, restriction on forest, lack of manpower at the family, etc.
The households who owned bio gas needed regular supply of dung. Therefore, they kept fewer animal on stall-fed basis. Similarly, the local breeds of buffaloes and cows were gradually replaced by improved ones. The improved breeds of livestock needed more care and people invested more money on the animals. Therefore, they did not let the animals stray because of their high cost. The second reason was restriction on grazing in community forest. The third reason was that in the past herding was the duty of children. As noted, most of the children of sample households went to school. Similarly, adult males of the area under study were hardly available at the village as they went outside to earn their livelihood. In the past, some families had a tendency to keep domestic servants for animal herding. The transportation facilities in the district created other type of wage labouring opportunities within and outside of the village, Therefore, the members of the poor households started to give little preferences to herding works. Difficulty in recruiting herders was one of the responsible factors to decrease the livestock size in the study village.

Balahara had no open grazing land and Kharka (seasonal/ individual/communal gazing land). As recorded there was 8 ropanis of grazing land in the village. The forest lands had been restricted for grazing animals since 1993. Therefore, the majority of the households shifted their herding place from forest grazing land to stall feeding. Scarcity of grazing land and, need of dung and urine for bio-gas are the major factors to change the herding practices of the people. Change on herding practices created new social involvement. In the past, for example, herding was the duty of children but now collecting dung, operating gas-pit and taking care the livestock are of the duties of the adult population also.

\section{Change in Firewood Consumption Pattern}

Firewood is used for different purposes such as heating, cooking, etc. In addition, it provides many other amenities to the 
villagers such as heating the houses particularly in the upper parts of this area where the winter is fairly severe. In 1991, the per capita consumption of firewood was $617.57 \mathrm{~kg}$. in the village annually which was higher than national level firewood consumption. The rate of firewood consumption has significantly changed within a decade. The rate of firewood consumption is presented in table : 3

Table : 3 Rate of Firewood Consumption on the Basis of Caste and Ethnicity

\begin{tabular}{llccc}
\hline Group & $\begin{array}{l}\text { Caste/ } \\
\text { Ethnic }\end{array}$ & $\begin{array}{c}\text { No. of } \\
\text { HHS }\end{array}$ & $\begin{array}{c}\text { Annual per } \\
\text { Capital of } \\
\text { Firewood in } \\
1991(\mathrm{Kg})\end{array}$ & $\begin{array}{c}\text { Annual Per } \\
\text { Capita of } \\
\text { Firewood in } \\
2001(\mathrm{Kg})\end{array}$ \\
\hline 1 & Rai & 10 & 700.64 & 415.15 \\
2 & Chhetry & 10 & 403.33 & 301.0 \\
3 & Magar & 10 & 738.26 & 504.14 \\
4 & Brahmin & 10 & 421.76 & 276.0 \\
5 & Tamang & 10 & 508.05 & 357.11 \\
6 & Newar & 10 & 605.10 & 212.00 \\
7 & Kami & 10 & 1085.70 & 585.00 \\
\hline 8 & Damai & 10 & 600.00 & 387.00 \\
\hline
\end{tabular}

Source: Field Survey, 1991 and 2001

The per capita firewood consumption rate has significantly decreased in 2001 compared to 1991. As mentioned in 1991, people had access to all forest areas of the village. Now people are depended only on forest to collect the forest resources. The Kamis shared the highest percentage of firewood both in 1991 and 2001. However, the ratio of consumption has declined by fifty percent. There is a cultural reason behind the use of such a large volume of firewood by blacksmiths. According to blacksmiths, themselves, about fifty percent of the firewood was converted into charcoal for manufacturing agricultural implements such as spade, sickle, Khukuri(traditional knife), etc. In addition, some of them supplied charcoal to Dhankuta bazaar for sale. However, such kind of practices are largely controlled with the establishment of CFs. The number of households collecting firewood from the own land was small in 1991, i.e. 5 HHs. This figures exceeds in 15 households in 2001. Among the ethnic/caste groups, the households of Brahmin and Rai consume the highest proportion of firewood collected from the owned land. Table 4 presents the firewood collection pattern of two different periods.

Table No. 4 Firewood Collection Pattern of the Respondents on the Basis of Caste and Ethnicity

\begin{tabular}{|c|c|c|c|c|c|c|c|c|}
\hline \multirow{2}{*}{$z_{\dot{\omega}}$} & \multirow{2}{*}{ 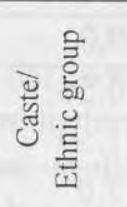 } & \multirow{2}{*}{$\begin{array}{l}\stackrel{0}{\Xi} \\
\frac{1}{0} \\
\dot{0}\end{array}$} & \multicolumn{3}{|c|}{$\begin{array}{c}\text { Method of Firewood } \\
\text { Collection } 1991\end{array}$} & \multicolumn{3}{|c|}{$\begin{array}{c}\text { Source of Firewood } \\
\text { Collection } 2001\end{array}$} \\
\hline & & & 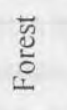 & 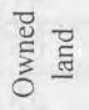 & $\frac{\omega}{\stackrel{\omega}{5}}$ & 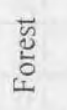 & 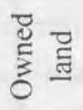 & $\stackrel{\text { ¿ }}{\stackrel{5}{0}}$ \\
\hline 1 & Chhetry & 10 & 9 & 1 & - & 7 & 3 & - \\
\hline 2 & Magar & 10 & 10 & - & - & 10 & - & - \\
\hline 3 & Brahmin & 10 & 9 & 1 & - & 6 & 4 & - \\
\hline 4 & Rai & 10 & 8 & 2 & - & 5 & 5 & - \\
\hline 5 & Tamang & 10 & 9 & 1 & - & 8 & 2 & - \\
\hline 6 & Newar & 10 & 8 & - & 2 & 6 & 1 & 3 \\
\hline 7 & Kami & 10 & 10 & - & - & 10 & - & - \\
\hline 8 & Damai & 10 & 10 & - & - & 10 & - & - \\
\hline & Total & 80 & 75 & 5 & 2 & 62 & 15 & 3 \\
\hline
\end{tabular}

Source: Field Survey, 1991 and 2001.

\section{Change in Timber Consumption}

Timber is used in the study village for the construction of houses and cow shed. In the area under study, houses are mostly made of stones and timber. Timber is used for door and window frames, shutters, roof rafters and ceilings. In 1991, the houses were generally two storeyed and the roofing is mostly conical thatched. Bamboo was used for thatching the cattle shed and houses. In addition, timber provided agricultural equipment such as plough, yoke, handle for hoe, etc. In the present study, attempt has been made to compare the past and present timber consumption pattern of the sample households on the basis of caste and ethnicity. 
Table : 5 Timber consumption with Regard to Caste Ethnic Group (cu.ft)

\begin{tabular}{|l|c|c|c|}
\hline $\begin{array}{c}\text { Caste/ } \\
\text { Ethnic group }\end{array}$ & $\begin{array}{c}\text { No of } \\
\text { HHs }\end{array}$ & $\begin{array}{c}\text { Annual Per } \\
\text { Capita of } \\
\text { Timber- 1991 }\end{array}$ & $\begin{array}{c}\text { Annual Per } \\
\text { Capita of timber- } \\
2001\end{array}$ \\
\hline Rai & 10 & 27.94 & 12.15 \\
\hline Chhetry & 10 & 27.50 & 12.95 \\
\hline Magars & 10 & 32.39 & 10.5 \\
\hline Brahmins & 10 & 22.53 & 9.0 \\
\hline Tamangs & 10 & 47.92 & 10.56 \\
\hline Newars & 10 & 63.00 & 11.59 \\
\hline Damai & 10 & 35.60 & 7.0 \\
\hline Kami & 10 & 40.00 & 8.5 \\
\hline Total & 80 & & \\
\hline Sowre: & & & \\
\hline
\end{tabular}

Source : Field Survey, 1991 and 2001

For 80 sample households, the per capita consumption of timber was $37.57 \mathrm{cu}$. ft. per annum in 1991. The timber consumption rate was higher in 1991 at the area under study not only owing to any domestic requirement, but they had also a tendency to stock timber for future construction. With the introduction of community forestry timber consumption behaviour is regularized by forest user groups. Now one can get timber on the basis of his/her needs rather than wants. According to forest user groups' rule, a household gets fixed amount of timber on annual basis for agricultural equipments such as plough, yoke, etc. If someone's house is caught by fire, such a victimized family will extract some timber as per his needs. During the time of family separation FUG provided timber to the families to construct the houses. As observed, some families of the VDC under study have started to plant timber tree in their land for future security. There was a tendency to cut down big trees for the small purpose in 1991. However, cutting down the big trees for agricultural implements was not noticeable in 2001.
In 1991, among the 80 respondents, 77 respondents extracted timber from the forest. However, this tendency declined in 2001 because of the FUG formation and ownership feeling of the people. The housing pattern of the roadside significantly changed. In 1991, almost all houses were roofed by thatch grass. The follow up study shows that iron sheet was the roofing material of the roadside dwellers and well-to-do families.

\section{A New Innovation : Family Forest}

Systematic plantation of trees for fulewood, fodder, and timber was hardly observable in 1991. However, with the introduction to community forestry, individual family started to plant multipurpose trees to meet their fodder, firewood and timber demand. In the mid of 1990 s, the British road project started to plant the seedlings at both side of highway and encourage to the locals to plant trees on their land. The project also provided seedlings and technical support to the people. Now people have domesticated some trees at the edge of agricultural land. As Noronha and Spears (1985) noted, adopting family forestry implies a change in behaviour inasmuch as farmers didn't not previously plant fuel wood systematically Another trend during the last decade is the plantation of bamboo trees in the vertical slope of agricultural land. There was some tendency to grow bamboo plants for fodder, roofing and firewood in the past. However, after 1995, people were attracted towards bamboo farming because of its economic value in the local market. The price of single bamboo tree was Rs. $20-25$ in the beginning of 1991. The demand of bamboo tree is increased after 1995 and the price of a bamboo tree reached Rs 40-50.

\section{Change in Firewood Sale}

There were 10 sample households involved in firewood sale in 1991. As recorded, each day bundle of firewood was supplied in Dhankuta Bazar in the beginning of 1991. There were a large number of poor families involved in firewood sale up to 1993. After the construction of Dharan Dhankuta highway, some of the highway labourers started to live in the area under 
study adapting firewood sale as a means of livelihood. There was high demand of firewood in the district headquarter between the period of 1970s-1990s. As mentioned above, the population of the district headquarters increased with the establishment of regional headquarters in 1970s. However, the process of firewood sale dramatically declined in the mid of 1990s triggered by different factors. In 1993, most of the government forests of the adjoining areas were handed over to communities. Since then, the firewood sellers could not collect firewood freely. The price of firewood hiked in Dhankuta bazaar. In 1991, the price of one bundle firewood was not more than Rs. 25. But price of one bundle firewood went up Rs 70-75 in 1995. Before 1993, it took almost a full day to bring a bundle of firewood up to one's residence. The next day, early in the morning the same firewood was carried to Dhankuta bazaar. Thus, to sell one bundle of firewood needed one and half day's work. After 1993, one could not supply firewood on regular basis because of the restriction on community forests. Due to the high price of firewood the bazaar dwellers started to use alternative source of energy for cooking such as L.P. gas and Kerosene. The number of L.P. gas and Kerosene users were hardly 1 or 2 percent of the total households at Dhankuta Bazar in 1991. The percentage of L.P. gas and Kerosene users increased by 60 percent in the end of 2000 . In the time of follow up study in 2001, the number of firewood sellers decreased by 70 percent. Therefore, they left their firewood selling job and directly entered into national, regional and international labour markets for their survival. The wood sellers hardly participated in community forestry management. Because most of them were either landless or owned a small piece of land. The primary need of such households is to extract firewood from the forest to sell in the local market which is disturbed by community forestry. Similarly, they are skeptical towards the well off families because they think the benefit coming from the community forest would go to the well to do families. In this regard, Agrawal (quoted by Noronha and Spears, 1985: 236) stated that the poorer farmers and the landless are reluctant to contribute free labour for community projects since they feel the benefits would go to the few who are well off.

\section{Conclusions}

The people of Belahara have changed their strategies on forest consumption pattern since last ten years. Community forestry and bio-gas programs are the major catalysts of change. During the period between 1970 s to 1990 s, several new demands emerged on local forest resources as a result of outside intervention. The policies and performance of government institutions, development of infrastructure and social pressure affected the people's forest consumption pattern in the study area. Community forestry program regularized the people's behaviour on firewood, fodder and timber consumption. Similarly, government encouraged the locals to install the biogas in subsidy price in the study area. To cope with the scarcity of forest resources, people developed a set of strategies such as installation of bio-gas, starting family forest, keeping small number of livestock on stall-fed basis and changing on roofing pattern. Similarly, the firewood selling households felt threatened on their job and switched other type of wage labourings in regional, national and international level markets. The land utilization pattern of study area has changed to some extent. People of the area under study started to plant trees on the edge of agricultural land and slope area for their future security.

\section{REFERENCES}

ADB/HMG/N 1982. Nepal Agriculture Sector Strategy Study, Vol. No. II, Manila

Alternative Energy Promotion Center (AEPC), 2000. Renewable Energy Perspective Plan of Nepal, 2000-2020: A Approach, Lalitpur, Nepal.

Bennett, W. John, 1996. Human Ecology as Human Behaviour, Essays in Environmental and Development Anthropology, Transaction Publishers New Brunswick (U.S.A) and London (U.K.)

Beresford- Peirse, Henry, 1976. Forestry Food and People, FAO, Rome.

Central Bureau of Statistics, 2002. Report on the Household Consumption Survey of Rural Nepal 2000-/2001, National Planning Commission Secretariat HMG/Nepal. 
Cernea, M. Micheal, 1985. Putting People First, Washington DC: World Bank, 1985.

Chhetry, R.B. and T.R. Pandey, 1992, User Group Forestry in the Farwestern Region of Nepal. Kathmandu ICIMOD.

Dahal, D.R. 1994. A Review of Forest Users Groups: Case studies from Eastern Nepal. International Centre for Integrated mountain Development, Kathmandu, Nepal.

Fricke, Thomas E., 1993. Himalayan Households: Tamang Demograhpy and Domestic Processes, Book Faith India, Delhi.

Gilmour D.A. and Fisher, R.J. 1991. Villagers, Forest and Foresters: The Philosophy, Process and Practice of Community Forest in Nepal. Kathmandu, Sahayogi press.

HMG/Nepal, 1989. Economic Survey, Ministry of Finance, Kathmandu

ICINOD, 1986. Decentralized Energy Planning Management in the Hindukush Himalayas, ICIMOD, Kathmandu

Ministry of Finance HMG/Nepal, 2001. Economic Survey, Kathmandu.

Noronha, Raynmond and John S. Spears, 1985. "Sociological Variable in Forestry Project" In Michael M. Cernea (ed.) Putting People First Washington DC, World Bank.

Pokharel, Binod, 1991. Forest Consumption Pattern in Dhankuta M.A. Dissertation in Anthropology (Unpublished) Submitted to the Central Department of Sociology/Anthropology, T.U. Kirtipur.

Pokharel, Durga and Anthony B. J. willet, 1996. History of an Indigenous Community Management Organization in Nepal. Indigenous Organization and Development (ed.) peter Blunt and D Michael Warren, Intermediate Technology Publications Ltd. London, UK.

Saussan, J., B.K. Shrestha and L. P. Uprety 1995. The Social Dynamics of Deforestation: A Case Study from Nepal. Published in the UK and Europe by the Parthenon Publishing Group Limited Casterton Hall, carnforth, England.

Stevens, F. Stanley, 1993. Claiming the High Ground; Sherpas Subsistence and Environmental Change in the Highland Himalayan, Motilal Banarsidass Publishers Private Limited, Delhi, VDC, Record of Belahara, 2001.

Wallance, Michael, B. 1988. Research Report Series, WINROCK, Kathmandu

Wood and Energy Commission, 1987. Fuelwood Supply in the District of Nepal

\section{STRATEGIES AND PRACTICES OF ADVOCACY: GENDER ADVOCACY AGAINST TRAFFICKING IN WOMEN IN NEPAL *}

\author{
Meena Poude \\ Youba R. Luintel
}

\subsection{Introduction}

Advocacy is an organised and sustained campaign to get the interest of the marginalised people represented and addressed in public policy, attitudes or practices. It is a deliberate, systematic and organised way of influencing effective implementation of existing policy, change it or formulate alternative policies in favour of targeted area/group/issue. The goal of advocacy is to challenge the powerful in favour of the deprived and disadvantaged ones, such as Dalit, ethnic minorities, landless, women, children and older people.

While there has been a growing body of literature on empirical cases of trafficking in women, movement against it has been rarely documented and discussed. This paper attempts to critically analyse gender advocacy from the light of Social Relations Approach (SRA), especially from the framework of Institutional Analysis (IA). We argue that while trafficking in women has become a lucrative business for profit-making, a critical analysis of the institutions involved in it and a concerted

\footnotetext{
Ms. Poudel is a feminist activist and development anthropologist currently working as Program Representative for Oxfam GB in Nepal. Mr. Luintel is a sociologist specialising on gender issues and teaches gender course at Central Department of Sociology/Anthropology, Tribhuvan University
} 